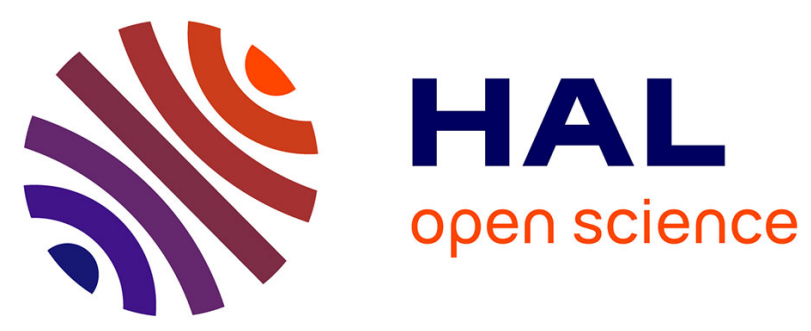

\title{
Natural Arsenic in Groundwater and Alkaline Lakes at the upper Paraguay basin, Pantanal, Brazil
}

\author{
Laurent Barbiero, S.A.C. Furquim, Vincent Vallès, S. Furian, Arnaldo \\ Sakamoto, A. T. Rezende Filho, Monique Fort
}

\section{To cite this version:}

Laurent Barbiero, S.A.C. Furquim, Vincent Vallès, S. Furian, Arnaldo Sakamoto, et al.. Natural Arsenic in Groundwater and Alkaline Lakes at the upper Paraguay basin, Pantanal, Brazil. BATTACHARYA P., MUKHERJEE A.B., BUNDSCHUH J., ZEVENHOVEN R., LOEPPERT R.H. Arsenic in Soil and Groundwater Environment: Biogeochemical interactions, health effects and remediation, elsevier, pp.101-126, 2007, Trace metals and other contaminants in the environment. hal00364414

\section{HAL Id: hal-00364414 \\ https://hal.science/hal-00364414}

Submitted on 26 Feb 2009

HAL is a multi-disciplinary open access archive for the deposit and dissemination of scientific research documents, whether they are published or not. The documents may come from teaching and research institutions in France or abroad, or from public or private research centers.
L'archive ouverte pluridisciplinaire $\mathbf{H A L}$, est destinée au dépôt et à la diffusion de documents scientifiques de niveau recherche, publiés ou non, émanant des établissements d'enseignement et de recherche français ou étrangers, des laboratoires publics ou privés. 


\section{Natural Arsenic in Groundwater and Alkaline Lakes at the upper Paraguay basin, Pantanal, Brazil}

L. Barbiéro ${ }^{\text {a, b,* }}$, S.C. Furquímc, V. Valles ${ }^{\text {d, S. Furian }}{ }^{c}$, A. Sakamoto ,

A. Rezende Filho ${ }^{\mathrm{e}}$, M. Fort ${ }^{\mathrm{f}}$

${ }^{a}$ Indo-French Cell for Water Sciences, Department of Civil Engineering, Indian Institute of Science, 560012 Bangalore, India

${ }^{b} I R D$ - UR 154, Laboratoire des Mécanismes de Transfert en Géologie, 14, avenue Edouard Belin, 31400 Toulouse, France

${ }^{c}$ Departamento de Geografia, Universidade de São Paulo, São Paulo, Brazil

${ }^{d}$ Université de Provence, Aix Marseille 1, France

${ }^{e}$ Departamento de Geografia, Universidade Federal do Mato Grosso do Sul, Três Lagoas, Brazil

${ }^{f}$ Laboratoire de Géomophologie Appliquée, Université de Paris 7, France

* Corresponding author : barbiero@ civil.iisc.ernet.in

Phone: +918022933127

Fax: +918023600223 


\begin{abstract}
A distinctive feature of Nhecolândia, a sub-region of the Pantanal wetland in Brazil, is the presence of both saline (alkaline) and freshwater lakes. Saline lakes were attributed to a past arid phase during the Pleistocene, but recent studies have shown that the geochemistry of the saline lakes arises from the current concentration process of fresh waters that is supplied to the Pantanal every year. The region is mainly used for cattle farming, more recently eco-tourism is becoming widespread and water conservation agencies worry about arsenic contents in surface and shallow ground water. The study was carried out along a $600 \mathrm{~m}$-long transect that linked a freshwater lake to a saline lake. The spatial distribution of arsenic is studied, based on soil morphology, according to $\mathrm{pH}$, redox conditions (Eh) and dissolved organic carbon (DOC), and also compared to distribution of major elements. Three main processes, responsible for the chemical variability, were identified: (1) the concentration of the solution under the influence of evaporation and the associated precipitations (Mg-calcite, illite, sodium carbonate); (2) oxidation of sulphides included in clay layers and subsequent development of acid conditions; (3) buffering of acid conditions by clay dissolution.

Arsenic contents are not affected by the last two processes ( 2 and 3) but evolve in proportion to the concentration. Arsenic concentrations in water ranged from $0.11 \mu \mathrm{g} / \mathrm{l}$ to $3.68 \mathrm{mg} / 1$, i.e. 368 times higher than the World Health Organization (WHO) guidelines for drinking water. The arsenic speciation [index word 1] as calculated from field conditions indicated that the As(V) redox state dominated in the groundwater and in the lakes, whereas some proportion of As(III) could occur on the shore and in the sediments of the saline lake. As(III) from the sediment can be remobilised and dispersed into the water following the disturbance of the sediments by cattle that come to drink water. Arsenic contents increased with most of the other dissolved species; hence competitive adsorption [index word 16] prevent dissolved arsenic regulation by solid phase reaction. Moreover, the $\mathrm{pH}$-values increased above 8 with increasing arsenic, favouring $\mathrm{As}(\mathrm{V})$ desorption. As a consequence, the good correlation established between arsenic contents and electrical conductivity $\left(r^{2}=0.97\right)$ should help to indirectly evaluate the arsenic contents in shallow groundwater and lakes of the region.
\end{abstract}

Keywords: Alkaline lake, Upper Paraguay Basin, Wetland, Pantanal, Brazil 


\section{Introduction}

Arsenic is known as a toxic and carcinogenic element, with a combination of high toxicity [index word 2] at relatively low concentration and high mobility in water with a $\mathrm{pH}$ range of many groundwaters (particularly the alkaline ones) and under a large range of redox conditions [index word 14]. Mobilisation of arsenic under oxidising conditions is known to be an important process responsible for arsenic contamination problems in many waters affected by oxidation of sulphide minerals, which often results from acid mine drainage. However, naturally occurring arsenic in groundwater of sedimentary basin has also recently emerged as a global problem (Bhattacharya et al., 2004). High concentrations of arsenic in ground water have been reported from different regions of the world, including South, Central and North America, and Asia. The most widespread arsenic enrichment occurs in a large region that covers portions of West Bengal (India) and Bangladesh (Bhattacharya et al, 2002a, b; Harvey et al., 2002; Zheng et al., 2004) with a high population density. Many case studies have been summarized in the review presented by Smedley and Kinniburgh (2002). Although high arsenic contents have been reported in the Chaco and La Pampa (Smedley et al., 2002; Bundschuh et al., 2004) in the middle and lower Paraguay basin respectively, nothing is known about arsenic in the upper Paraguay basin (Fig. 1), i.e. in groundwater of the Pantanal wetland mainly located in Brazil with parts of it in Bolivia and Paraguay [Take in Fig. 1 here].

Nhecolândia is a sub-region of the Pantanal wetland located between the rivers Taquari and Negro that is characterized by countless marshes and lakes, of which some are saline (salinas). Until now, the salt has always been attributed to alternating humid and arid phases during the Pleistocene (i.e., inherited from the past), but Barbiéro et al. (2002) have shown a unique geochemical family of waters evolving currently in an alkaline manner under the influence of evaporation [index word 3]. The geochemical composition changes gradually from feebly mineralised waters that flood the region during the rainy season to the strongly mineralised ones in the salinas. The salinas are an essential component of the principal economical activity of this region (i.e., cattle breeding). Being located in the extreme lowlands, these salinas provide water even during the driest periods, as well as valuable mineral supplements for cattle, which feed primarily on poor-quality local grass. Moreover, eco-tourism is becoming widespread and water conservation agencies worry about surface and ground water quality, because many toxic elements, and particularly arsenic could concentrate in alkaline conditions, exceeding the World Health Organisation's threshold values for drinking water. Under the influence of evaporation, the concentration of solutions and associated chemical precipitations have been identified as the main factors in the variability of the water chemistry in the region (65 samples) (Barbiéro et al., 2002). A spatial analysis in the same area (76 samples) has shown that the salinity is not evenly distributed, but suggests that the changes in chemical composition depend on local conditions at a distance less than the average distance between lakes, i.e., less than $500 \mathrm{~m}$ (Almeida et al., 2003). Therefore, the present study focused on the behaviour of arsenic in one alkaline lake and in the surrounding upland groundwaters where high concentration, $\mathrm{pH}$ and redox [index word 14] gradients have been reported (Barbiéro et al., 2002). Geochemical features are further interpreted according to the 
morphology of the soil system and the watertable fluctuations in order to identify the main processes responsible for chemical variability in the water and their impact on arsenic concentration.

\section{Regional setting}

The Pantanal of Mato Grosso, located between $16^{\circ} \mathrm{S}$ and $20^{\circ} \mathrm{S}$ and $58^{\circ} \mathrm{W}$ and $50^{\circ} \mathrm{W}$ at the centre of South America, covers an area of about 140,000 square km (Fig. 1) and is considered as the worlds largest wetland (Por, 1995). Its landscape comprises a variety of ecological sub-regions, including river corridors, gallery forests, perennial wetlands and lakes, seasonally flooded grasslands, and terrestrial forests. Put together, these natural features form a large and biologically diverse ecosystem. The northern, eastern, and southern borders of the Pantanal graben are clearly marked by the Brazilian highlands at an altitude of about 400 m (Chapada dos Parecís, Serra São Jerônimo, Chapada dos Guimarães, Serra do Maracajú, Serra da Bodoquena). There is an opening in the North, through which the Paraguay River flows southward. In the South, the Paraguay River crosses a narrow area between the mountains called "Fecho dos Morros," considered to be the limit of the upper Paraguay basin. The surrounding highlands consist of Precambrian and Palaeozoic rocks. They are locally iron and manganese-rich, but also contain large areas of limestone. The alluvial plain is 100 to $200 \mathrm{~m}$ above sea level, with a slight North-South and East-West gradient. Quaternary sediments, alluvial products of the Paraguay River effluents and tributaries, cover the plain (Klammer, 1982). Sediments are coarse grained sand locally cemented by iron oxides and covered by several meters of fine-medium white sands (Assine and Soares, 2004). The vast plain of the Pantanal wetland provides a gigantic natural flood control device for the storm waters resulting from torrential rainfall during the wet period. Each year, the main tributaries supplying the Pantanal overflow during the rainy season. With the flood, the depressions are inundated and form extensive lakes, which coalesce into larger water bodies. During the dry season, the floodwaters recede, resulting in a complex mosaic of grasslands, forests, lakes and marshes.

Nhecolândia, where the present study was carried out, is a 26,000-square km sub-region of the Pantanal plain that corresponds to the southern part of the alluvial fan of the Taquari River (Fig. 1). A distinctive feature is the presence of thousands of saline and freshwater lakes co-existing in close proximity. During the dry season, these lakes cover about $30 \%$ of the area. Among all the lakes of Nhecolândia, Morrison et al. (2000) identified 499 salty lakes, which make up about $1 \%$ of the total surface area. The seasonal floods of the Nhecolândia floodplain occur in three ways: (1) the over-bank flow of the Taquari river across its natural levees, (2) a backwater effect caused by the flooding of the Paraguay and Negro rivers and (3) local rainfall on lands with gentle slopes and therefore delayed drainage to river courses (Hamilton, 1999). The backwater effect caused by the Paraguay and Negro rivers can locally and temporarily reverse the flow of some tributaries (Hamilton et al., 1998). At any local part of Nhecolandia, the hydrologic regime is much more complex, and the ground water flows connecting the many lakes are not yet understood. The soil cover consists of sandy soils with small patches of clay and lime soils. High sodium contents are observed locally, particularly in southern Nhecolândia. The most frequent soil ("Plintossolos" according to the Brazilian classification) is characterized by low organic 
matter content and the presence of a deep green horizon, hardening irreversibly after air drying. The landscape is constituted by special features with typical regional denominations, which will be used throughout the article:

- The "lagoas" are temporary or permanent lakes with variable forms and dimensions. They can reach approximately two meters depth.

- The "salinas" are permanent salty lakes. They are generally 500 to $1000 \mathrm{~m}$ in diameter, 2 to 3 $\mathrm{m}$ deep (during the dry season), and most commonly well delimited and/or isolated by a stripe of dry land or "cordilheiras."

- The "cordilheiras" are narrow (200-300 m wide) and elongated sand hills (2 to $5 \mathrm{~m}$ high) covered by savanna vegetation (Cerrado).

- The "campos" are meadows covered by grass.

The climate is characterized by hot rainy summers from November to March and dry winters from April to October. The average annual precipitation is about $1000 \mathrm{~mm}$ and the annual evapotranspiration about $1400 \mathrm{~mm}$.

\section{Material and methods}

\subsection{Fieldwork}

The study was carried out at the experimental farm Nhumurim that is representative of the region and managed by the Brazilian Institute for Agricultural Research (EMBRAPA-Pantanal). The fieldwork was concentrated along a $600 \mathrm{~m}$ long sequence between a freshwater and a saline lake (Fig. 2). The soil is mostly composed of white structureless sand and around the saline lake it overlies a light sandy horizon with abundant blackish volumes of organic matter with frequent presence of calcareous nodules (Fig. 3). Beneath, there is a structureless, sodic and alkaline grey horizon with about 10-20\% clay. At depth, this clay horizon turns green and indurate. Furquím et al. (2004) have shown that the clay $(<2 \mu \mathrm{m})$ fraction consists largely of illite and to some extent of glauconite in both the grey and the green horizon, but the green horizon is hardened by a cement of amorphous silica [Take in Fig. 2 and 3 here].

Hydraulic conductivity of the representative horizons were measured using a Decagon ${ }^{\circledR}$ disk infiltrometer (Zhang, 1997). Sixteen piezometers were installed at the end of the dry season in October 1998. The topographic heights of the landscape and piezometers were determined by teodolite, and the depth of the groundwater table was measured every 10 days from October 1998 to October 2002. The set up of the study site was completed by the installation of 15 water table samplers along the sequence. Water table samplers consist of a simplified model of zero-tension lysimeter presented by Maitre (1991). The sampler is a $100 \mathrm{ml}$ closed polypropylene container, with holes measuring $2 \mathrm{~mm}$ diameter and wrapped with a synthetic tissue to prevent clogging by soil particles. A polypropylene pipe with $1 \mathrm{~mm}$ inside diameter is inserted in the cap of the container limiting the contact with the outer atmosphere. Auger holes ( $7 \mathrm{~cm}$ in diameter) were made down to the water table where the sampler was placed and the hole was filled up again in the same order of the excavated horizons. Two sets of samples were collected, one in October 2000 and the other during the severe drought in July 2003, 
when no water was found at P5 to P15. Samples were taken from the water table samplers by gentle pumping with a hand vacuum pump in order to prevent drastic changes in the redox conditions [index word 14]. Redox (Eh) was immediately measured ( $\sim 5$ seconds) using a platinum probe. Temperature (T), conductivity (EC) and $\mathrm{pH}$ were determined in the field before samples were filtered with a $0.2 \mu \mathrm{m}$ cellulose-acetate membrane syringe filter and collected in acid washed polyethylene containers. Samples collected for analysis of cations and arsenic were acidified using ultrapure $\mathrm{HNO}_{3}$. Samples for anion and dissolved organic carbon (DOC) analysis were not acidified. All samples were collected in duplicate. Eh was also measured in the sediment at different places of the Lagoa (25 measurements) and salina (15 measurements).

\subsection{Laboratory work}

Soil samples: The cation-exchange capacity (CEC) was measured by the $1 \mathrm{M} \mathrm{NH}_{4} \mathrm{OAcetate}$ method at $\mathrm{pH}$ 7. $\mathrm{Ca}^{2+}, \mathrm{Mg}^{2+}, \mathrm{Na}^{+}$and $\mathrm{K}^{+}$ions (equivalent fractions) were extracted with $1 \mathrm{M} \mathrm{NH}_{4} \mathrm{Cl}$ and quantified by atomic absorption spectroscopy. The $<2 \mu \mathrm{m}$ clay fraction was separated by sedimentation after destruction of the organic matter with $\mathrm{NaOCl}$ ( $\mathrm{pH}$ 9.5). Analysis of $\mathrm{Si}, \mathrm{Al}, \mathrm{Fe}, \mathrm{Ca}, \mathrm{Mg}, \mathrm{Na}$ and $\mathrm{K}$ were performed on compacted clay patches using electronic microprobe fitted with wavelength dispersive spectrometers.

Water samples: Total alkalinity was determined by acid titration with $\mathrm{HCl}$. Major elements were analysed by ion chromatography for anions $\left(\mathrm{F}, \mathrm{Cl}^{-}, \mathrm{Br}^{-}, \mathrm{NO}_{3}{ }^{-}, \mathrm{SO}_{4}{ }^{2-}, \mathrm{PO}_{4}{ }^{3-}\right)$, atomic adsorption spectroscopy for cations in 2000-samples and ICP-MS for cations in 2003-samples $\left(\mathrm{K}^{+}, \mathrm{Na}^{+}, \mathrm{Ca}^{2+}\right.$, $\mathrm{Mg}^{2+}$ ). Si, minor elements and trace elements including arsenic were determined by ICP-MS. Analysis were interspersed with standard reference material and checked against the same. Accuracy for most of the analysis of the major elements were shown to be below $2 \%$ without dilution and within $5 \%$ for analysis carried out after the highest dilution (500 times). Dissolved Organic Carbon was analysed by combustion.

\subsection{Statistical treatment}

A principal component analysis [index word 4] based on the correlation matrix was performed on EC, major elements, DOC and arsenic contents, in order to identify and quantify the processes responsible for the variability in water quality.

\subsection{Concentration diagrams}

Data from 2000 and 2003 samplings are presented in the concentration diagrams that were built using $\mathrm{Na}^{+}$as a conservative tracer to estimate the concentration factor. Therefore, if a Na-salt precipitation occurs then the concentration factor will be underestimated and this hypothesis needs to be verified in the case of saline waters.

\subsection{Thermodynamic modelling [index word 5]}

The ions activity and speciation [index word 1], the mineral equilibrium calculations as well as evaporation process modelling were performed by the AQUA code (Valles et al., 1996). AQUA is an ion pair model built around a Debye-Hückel extension for saline solutions. Indeed the Debye-Hückel law itself deals only with (long-range) electrostatic interactions [index word 6] and gives poor results 
when applied to brines, hence, various extensions of it have been suggested. The Scatchard extension (Scatchard, 1968) is among the most commonly used but another extension was used for calculation with the model AQUA (Valles et al., 1996). The latter extention is adequate for electrolyte solutions with ionic strengths up to $1 \mathrm{M}$ which is higher than the upper value occurring in the alkaline lakes of Nhecolândia. The model presents the following specifications: (1) The program uses continuous fraction iteration and stops when the relative variation is less than $0.1 \%\left(\delta\right.$ activity/activity $\left.<10^{-3}\right)$ and (2) The files are documented for 90 dissolved species (62 ionic and 28 neutral) and 25 relevant mineral thermodynamic data were used in this study for evaluating saturation states $\left(\log \mathrm{Q} / \mathrm{K}<10^{-3}\right.$ for minerals allowed to be dissolved or precipitated). This model AQUA was tested for diverse geochemical contexts, such as the neutral saline soil in Tunisia and Algeria (Valles et al., 1997), the alkaline soils of Sahelian Africa (Valles et al., 1989; Marlet et al., 1996; Barbiéro et al., 2001), and for the minor elements, namely, fluoride in the alkaline conditions of the Ethiopian rift (Chernet et al., 2001). In the modelling, the partial pressure of $\mathrm{CO}_{2}$ [index word 8] is calculated from the $\mathrm{pH}$ and from alkalinity data while $\mathrm{O}_{2}$ fugacity [index word 7] is calculated from $\mathrm{pH}$, Eh and T.

\subsection{Residual alkalinity [index word 10]}

The concept of residual carbonates derived originally from Eaton (1950), was later redefined in terms of "residual alkalinity" which is the difference between carbonate alkalinity and calcium amounts in the solution (Hardie and Eugster 1970; Van Beek and Van Breemen 1973). In other words, Calcite Residual Alkalinity is defined as $\mathrm{RA}_{\text {calcite }}=$ Alk. $-\left[\mathrm{Ca}^{2+}\right]$, where Alk. denotes the carbonate alkalinity and squared brakets [ ] denote the molalities in eq/l. When a solution concentrates through evaporation and reaches saturation with respect to calcite, two cases may arise. 1) If the calcium equivalent is larger than the carbonate alkalinity, then the calcium molality increases, alkalinity [index word 9] decreases, and thus the solution evolves in a saline manner. 2) If the calcium equivalent is smaller than the carbonate alkalinity, then the molalities change in the opposite direction and the solution becomes alkaline. The residual alkalinity concept was later generalised [index word 11] to successive precipitations of several minerals containing calcium or carbonate, for example, calcite followed by gypsum $\left(\mathrm{RA}_{\text {calcite+gypsum }}=\mathrm{Alk}-\left[\mathrm{Ca}^{2+}\right]+\left[\mathrm{SO}_{4}{ }^{2-}\right]\right.$; Droubi et al. 1980). When the saturation with respect to gypsum is reached, again two cases may arise. 1) If the calcium equivalent is larger than the sum of Alk. $+\mathrm{SO}_{4}{ }^{2-}$, then calcium molality increases and alkalinity and sulphate decrease during evaporation. 2) If the calcium equivalent is smaller than the sum Alk. $+\mathrm{SO}_{4}{ }^{2-}$, then calcium decreases and alkalinity and sulphate increase. In general, changes are observed in the concentration rate of the elements when saturation is reached with respect to a new mineral. Therefore, the concentration of certain elements can decrease, increase again, or simply fluctuate along the evaporation process. The residual alkalinity concept is used here in order to interpret the changes occurring in the evolution of each element when waters become more saline.

\section{Results}

4.1. Soil and water-table 
The contact between the sand and the top of the grey or green clay layer is undulating and the depth until the contact from the top soil is $6 \mathrm{~m}$ in the high grounds and $20 \mathrm{~cm}$ close to the saline lake (Fig. 3). The higher level of the clay layer is located between piezometer P2 and P3 and at a distance of about 40 $m$ from the average shore location of the salina. The $\mathrm{Na}$ and $\mathrm{K}$ equivalent fractions $\left(\mathrm{E}_{\mathrm{Na}}, \mathrm{E}_{\mathrm{K}}\right)$ increase with the increase in soil $\mathrm{pH}$ to reach values of about $50 \%$ and $35 \%$ respectively in the clay layer. The analysis of the clay fraction of both grey and green horizons revealed the following composition: $\mathrm{Si}$ (60 to $70 \%$ ), $\mathrm{Al}$ (15 to $25 \%$ ), $\mathrm{K}$ (6 to $9 \%$ ), $\mathrm{Fe}$ (4 to $7 \%$ ), $\mathrm{Mg}$ (2 to $3 \%$ ) and $\mathrm{Ca}$ (1 to $6 \%$ ). Similar clay horizons that are discontinuous are occurring below the lagoa. The transition from the sand to the clay layer is usually abrupt, but appears more progressive and with a rust-coloured transition near G6 and below the lagoa. The rust coloured transition is sandy but presents remnants of grey clay horizon.

During the wet season in 2000 and the dry season in 2001, two representative water levels are shown in Figure 3. During the wet season, the water table is almost horizontal from P15 to P3, with a slight depression in the cordilheira under the forested area and the water level dips down from P3 to the salina. During the 2001-dry season, the lagoa did not dry completely. The water level was almost horizontal from the lagoa to P3. In P2, the water level was $15 \mathrm{~cm}$ deeper and located in the impermeable green horizon. We assumed that the sampler G1 was located at the top of the water level at this date because air bubbles were observed during pumping. This level was still $40 \mathrm{~cm}$ higher than the water level in the salina. The fluctuation of the water level in P2 and P3 from October 1998 to October 2002 is depicted in Figure 4. [Take in Fig. 4 here] It indicates that the level at P3 is usually higher than at P2. After heavy storms that occurred during the rainy season, the water level exceptionally increased faster in P2 than in P3, inverting the gradient for a short period of about 5-10 days. The hydraulic conductivity of the sandy horizon is high of about $1710^{-3} \mathrm{~cm} / \mathrm{s}$ and decreases $410^{2}$ times lower in the grey horizon and about $10^{3}$ times lower in the green impermeable horizon.

The water quality differs along the transect, where the most saline alkaline waters occur on the north towards the saline lake and freshest waters in the cordilheira area (Fig. 5). Samples taken close to the lagoa are about 10 times more concentrated than those from the middle of the cordilheira. Saline waters are also observed in samplers G5 and G6, located close to the rise of the clay layer but on its southern slope. The water collected at G6 do not exhibit intermediate chemical characteristics between the saline and freshwater poles. It is saline but has a very low pH reaching 3.77 in 2000 and 4.25 in 2003 [Take in Fig. 5 here].

\subsection{Chemical variability}

The summary statistics for water chemistry are presented in Table 1. [Take in Table 1 near here] The ionic strength of the solutions varied from $1.2510^{-4} \mathrm{M}$ to $0.973 \mathrm{M}$. The total dissolved ion concentration based on electrical conductivity varied by a factor of 498 in October 2000 and 1018 in July 2003. According to the sodium content, the most mineralised solution was about 27000 times more concentrated than the least mineralised one. The less saline solution were of $\mathrm{Na}-\mathrm{K}-\mathrm{HCO}_{3}$ type, whereas the most saline ones were of $\mathrm{Na}-\mathrm{HCO}_{3}$ type. Sulphate contents were low, reaching only $5.23 \mathrm{mM}$ for 
the higher value in the data set. The solution collected in sampler G6 had a negative alkalinity in 2000 and as well as in 2003, which is consistent with the low pH measured.

Dissolved arsenic showed a large relative standard deviation in the set of data and varied at a large range in $2000(0.11$ to $266 \mu \mathrm{g} / \mathrm{L})$ and as well as in $2003(1.44$ to $3680 \mu \mathrm{g} / \mathrm{L})$, i.e., the highest concentration exceeded 26 times in 2000 and 368 times in 2003 the guidelines set by World Health Organization (WHO) [index word 12] for drinking water $(10 \mu \mathrm{g} / \mathrm{l})$. The arsenic concentration was 96 and 6.8 times below the WHO limits in the most diluted samples of 2000 and 2003 respectively. The F contents varied from values below the detection limit to $89 \mathrm{mg} / \mathrm{l}(4.7 \mathrm{mM})$, i.e. 60 times higher than the WHO guideline for this element $(1.5 \mathrm{mg} / \mathrm{l})$. The correlation matrix showed a close relationship between $\mathrm{EC}, \mathrm{Na}^{+}, \mathrm{SO}_{4}{ }^{2-}, \mathrm{K}^{+}, \mathrm{F}$, arsenic and alkalinity. A moderately close relationship was observed between these variables and $\mathrm{Cl}^{-}$, and between $\mathrm{Cl}^{-}$and DOC. The examination of the singular values (Table 2) revealed that the axis of the first factorial plan accounted for $66 \%$ and $14 \%$ of the variance [index word 15] of the data set [Take in Table 2 near here]. The first factorial axis opposed saline and fresh solutions, whereas the second axis opposed $\left(\mathrm{Ca}^{2+}, \mathrm{Mg}^{2+}\right)$ with $\left(\mathrm{Na}^{+}, \mathrm{SO}_{4}{ }^{2-}, \mathrm{EC}, \mathrm{Cl}-\mathrm{As}\right)$, and alkalinity [index word 9], $\mathrm{F}^{-}$and $\mathrm{K}^{+}$are located at intermediate position. The third axis of the PCA explained $11 \%$ of the variance. It opposed the samples collected at G6 with the rest of the sampling in 2000 as well as in 2003, and also associated the samples with low $\mathrm{pH}$, low $\mathrm{SO}_{4}{ }^{2-}$ and high $\mathrm{Cl}^{-}$amounts.

A large range of Eh was observed from $-180 \mathrm{mV}$ to $+400 \mathrm{mV}$ in the water samples. Lower Eh values were measured close to the salina. Moreover, Eh decreased down to $-370 \mathrm{mV}$ in the sediment of the saline lake, whereas it was always around $+200 \mathrm{mV}$ in the sediments of the lagoa. Along the first axis of the PCA, high and low Eh were associated to fresh and saline water respectively.

The DOC ranged from 0.44 to $1.110^{3} \mathrm{mg} / \mathrm{l}$ and high values were associated to saline solution with high $\mathrm{pH}$ along the first factorial axis of the PCA.

The arsenic speciation [index word 1] calculated from the field conditions indicated changes in the form of arsenic along the transect (Figs. 6 and 7). In diluted solutions with neutral $\mathrm{pH}$ and high Eh, arsenic may be dominated by $\mathrm{H}_{2} \mathrm{AsO}_{4}{ }^{-}$. When the $\mathrm{pH}$ increases $\mathrm{HAsO}_{4}{ }^{2-}$ may dominate. Then with increasing $\mathrm{pH}, \mathrm{DOC}$ increased, Eh decreased and the proportion of $\mathrm{H}_{3} \mathrm{AsO}_{3}{ }^{0}$ increased and may shift to $\mathrm{H}_{2} \mathrm{AsO}_{3}{ }_{3}^{-}$. On the other hand, the samples exhibiting very low $\mathrm{pH}$ value (3.77 and 4.25) may primarily be dominated by $\mathrm{H}_{2} \mathrm{AsO}_{4}{ }^{-}$and secondarily by $\mathrm{H}_{3} \mathrm{AsO}_{3}{ }^{0}$, and relatively high proportion of $\mathrm{H}_{3} \mathrm{AsO}_{4}{ }^{0}$ may occur [Take in Fig. 6 and 7 near here].

The less mineralised solutions were shown under-saturated with respect to calcite whereas most of the samples were saturated or slightly over-saturated with respect to the same. All samples were undersaturated for neutral salts like gypsum or halite. The solution is calculated to be under-saturated with respect to fluorite in most of the samples, and reaching saturation only in some of the most saline samples collected in 2003. Under saturation is also calculated for arsenolite $\left(\mathrm{As}_{2} \mathrm{O}_{3}\right)$, arsenopyrite (FeAsS) and orpiment $\left(\mathrm{As}_{2} \mathrm{~S}_{3}\right)$. Relatively high $\mathrm{Ba}^{2+}$ contents were found in the samples taken at G6, which are saturated with respect to barite $\left(\mathrm{BaSO}_{4}\right)$ in 2000 and $2003(\log (\mathrm{Q} / \mathrm{K})=0.21$ and 0.12 respectively). In the salina the most concentrated solution reached saturation with respect to nahcolite, 
and on the shore sodium carbonate precipitation was observed. Therefore, $\mathrm{Na}^{+}$is theoretically a convenient indicator to estimate the concentration factor of the samples through evaporation, except for the most concentrated sample in which the concentration factor could be under-estimated. On the concentration diagrams (Fig. 8), the solid lines are unit slope lines, i.e., a hypothetical evolution in proportion to the sodium contents. Alkalinity, $\mathrm{F}^{-}$and $\mathrm{K}^{+}$increase in proportion to the sodium contents for $\mathrm{Na}^{+}<0.2 \mathrm{mM}$ (Fig 8a, c and g) [Take in Fig. 8 near here]. They increase less steadily for $\mathrm{Na}$ between $0.2-20 \mathrm{mM}$, and again increase proportionately with higher concentration of $\mathrm{Na}^{+}$. The samples taken in G6 were not drawn on Figure 8a because their negative alkalinity was incompatible with the logarithmic scale used for the axis. The chloride molalities increase in proportion to $\mathrm{Na}^{+}$and could also be used for the estimation of the concentration factor. The acid samples collected at G6 have $\mathrm{Cl}$ contents almost double of other samples with similar $\mathrm{Na}^{+}$concentration. The sulphate plot is scattered and exhibits relatively high values for $0.03<\mathrm{Na}^{+}<1.5 \mathrm{mM}$. For higher concentration factor, $\mathrm{SO}_{4}{ }^{2-}$ increases in proportion to $\mathrm{Na}^{+}$. Acid samples collected in $\mathrm{G} 6$ have much lower $\mathrm{SO}_{4}{ }^{2-}$ than other samples with similar $\mathrm{Na}^{+}$. Calcium and magnesium increases proportionately to the sodium for $\mathrm{Na}^{+}$ ranging from 0.03 to $5 \mathrm{mM}$, and decrease for higher $\mathrm{Na}^{+}$although their plots are more scattered. Arsenic contents evolve in proportion to the concentration factor. Fresh solution with pH below 8 are saturated with respect to chalcedony (about $0.7 \mathrm{mM}$ ) and Si increases with increasing $\mathrm{pH}$ (above 8) up to $3.74 \mathrm{mM}$.

The simulated evaporation of dilute water (dotted line on Figure 8) is consistent with the evolution highlighted from the concentration diagrams of the observed data; a good agreement with the evolution of alkalinity, $\mathrm{Cl}^{-}$and As is noted. The simulation is also consistent with the significant control of $\mathrm{Ca}^{2+}$ and $\mathrm{Mg}^{2+}$. However it is not in agreement with the gap observed between G6 and the rest of the sampling, nor with $\mathrm{SO}_{4}{ }^{2-}$ data at low concentration factor. Also the simulation does not agree with the scatter plot of $\mathrm{K}^{+}$and $\mathrm{F}^{-}$.

\section{Discussion}

\subsection{Soil system}

Similar soil horizons occur on the shore, below both the salina and the lagoa. The $\mathrm{E}_{\mathrm{Na}}$ of these horizons is in equilibrium with the saline alkaline environment of the salina, whereas the rust transition at the lagoa indicates dissolution of the clay fraction and readjustment with the freshwater. Moreover, the cementation of the clay layer by amorphous silica necessarily occurs in an alkaline environment similar to the one at the salina. Therefore, the lagoa is likely to have been a former salina that is currently supplied with fresh water and hence desalinised. Calcite precipitates in the cordilheira and on the shore of the salina. High $\mathrm{pH}$ conditions favour large dissolved organic carbon contents, that precipitate into blackish volumes because of evaporation on the shore of the salina. The rise of the clay layer appears as a continuous ring around the salina and reaches almost the same topographic level in all transects. Therefore it is likely to have formed by clay precipitation in the alkaline environment related to the present water flow, i.e., to the hydrological regime of the salina. The clay formation is consistent with the water geochemistry that reached saturation with respect to illite, the main constituent of the clay 
fraction (Furquím et al., 2004). Among the major elements, the clay fraction incorporates K, and to some extent $\mathrm{Mg}$ and $\mathrm{Ca}$, and therefore it is likely to contribute to the regulation of these elements in solution.

The rust transition and the acid conditions detected at G6 indicate oxidation of sulphide minerals included in the grey and green layers. Similar acid conditions may occur in the rust transition below the lagoa, but we cannot verify this since no sampler was placed into the rust transition layer. The acid conditions are buffered by the dissolution of the clay fraction as indicated by the remnants of the grey clay horizon in the rusty-sand material of the transition. Illite is likely to be more involved with the buffering [index word 13] of the acid conditions because it has an higher buffer capacity than glauconite.

\subsection{Watertable fluctuations}

The water table fluctuates into a sandy material over the grey or green material detected on the shore and below the salina, and also below the lagoa. Although the clay proportion is low, the high sodium equivalent fraction $\mathrm{E}_{\mathrm{Na}}$ of the clay layers reduces water infiltration rates at the contact between the sandy and the clay horizons. Therefore, the rise of these layers occurring between P2 and P3 behaves as a "threshold", provoking a flow of water usually directed towards the saline lake. During the wet season, the water table rises and moves from the lagoa and upland towards the depression of the salina. As a consequence, $\mathrm{Na}^{+}$content increases in the salina and the shore through evaporation $(\mathrm{E} / \mathrm{P}=1.4)$, and so do most ion concentrations. On the contrary, during the dry season, the water table is lower and the clay layer between P2 and P3 acts as a barrier against the back flow of saline water towards the fresh sandy aquifer. Such a back propagation occurs temporarily during the rainy season with intensive rainfall, when the gradient is inverted between P2 and P3, and only when the level at P2 is higher than the morphological threshold provoked by the top of the clay layer. The above hydrological regime should explain how wetlands subject to the same amount of evaporation [index word 3] and rainfall have such different dissolved ion concentration and also how saline and fresh water lakes co-exist in close proximity in Nhecolândia. The same hydrological regime of the lakes is in agreement with the results of Almeida et al. (2003), who concluded that the changes in water salinity is due to very local processes occurring between the lakes.

\subsection{Chemistry of major elements}

The principal component analysis [index word 4] revealed 3 strong processes that are partially correlated in the landscape: 1) The concentration under the influence of evaporation, 2) Redox processes that oppose oxidized upland and reduced lowland with a strong vertical variability, and 3biological processes generating organic compounds with $\mathrm{pH}$-driven solubility.

The percentage of the variance [index word 15] explained by the first factorial axis of the PCA, which represents the concentration of the solution, is very high considering the number of chemical parameters involved in the calculation. Therefore, the concentration of chemical species due to evaporation appears as the principal process responsible for the chemical variability along the transect. Evaporation is enough to explain $\mathrm{Cl}^{-}$and total-arsenic concentration in water. The close relationship 
between alkalinity, $\mathrm{F}^{-}$and $\mathrm{K}^{+}$and the elements that are generally used to estimate the concentration factor $\left(\mathrm{Na}^{+}, \mathrm{Cl}^{-}\right)$indicates that they are not strongly affected by control processes when the waters evaporate. In the fresher waters, carbonate alkalinity is higher than $\mathrm{Ca}^{2+}$, i.e. the $\mathrm{RA}_{\text {calcite }}$ is positive (Alk. $-\left[\mathrm{Ca}^{2+}\right]>0$ ). Thus, when the solutions concentrate and calcite precipitates, calcium concentrations decrease and the carbonate alkalinity increases, although less rapidly than the sodium molalities, because some of the alkalinity is taken up from the solution by calcite formation. This evolution is consistent with the law of calcite residual alkalinity.

Calcium is mostly controlled by calcite precipitation, but its control is frequently strengthened by formation of fluorite in alkaline environments (Barbiéro et al., 2001; Chernet et al., 2001). Indeed, a sink of $\mathrm{F}^{-}$seems to be identified on the concentration diagram because fluoride contents increased less rapidly than the concentration factor. Fluorite is the least soluble F-containing mineral that might be expected to form and limit $\mathrm{F}^{-}$concentrations in low temperature systems. In a context of positive $\mathrm{RA}_{\text {calcite+fluorite }}\left(\mathrm{Alk}-\left[\mathrm{Ca}^{2+}\right]+\left[\mathrm{F}^{-}\right]>0\right)$, if $\mathrm{F}^{-}$is controlled by the formation of fluorite, its contents will increase just like alkalinity [index word 9], which could explain the high fluoride concentration occurring in the salina. The control of $\mathrm{F}^{-}$does not necessarily imply the formation of fluorite from calcium and fluoride. Fluorite deposits could result from replacement reactions of calcite by fluorite with alkaline and fluoride bearing solutions as observed by Icole et al. (1990). However, this process implies that the solutions are saturated with respect to $\mathrm{CaF}_{2}$, which is not the case along the transect. Indeed, although the saturation is reached for the most saline samples, the control of $\mathrm{F}^{-}$is occurring in more dilute solution with $\mathrm{Na}^{+}$concentration close to $0.2 \mathrm{mM}$, and with an absolute undersaturation for fluorite $(\log (\mathrm{Q} / \mathrm{K})$ of about -2$)$. Therefore, the precipitation of $\mathrm{CaF}_{2}$ cannot be responsible for the control of $\mathrm{F}^{-}$observed in the solution for $\mathrm{Na}^{+}$above $0.2 \mathrm{mM}$.

In the fresh water, high sulphate concentrations are observed that cannot be explained by concentration or dilution processes. The higher concentration in the fresh water indicates a source of $\mathrm{SO}_{4}{ }^{2-}$ around the lagoa (Fig. 8d). The source of sulphate is likely to be from the oxidation of sulphide from the clay layers through the following reaction, $\mathrm{FeS}_{2}+15 / 4 \mathrm{O}_{2}+7 / 2 \mathrm{H}_{2} \mathrm{O} \rightarrow \mathrm{Fe}(\mathrm{OH})_{3}+2 \mathrm{SO}_{4}{ }^{2-}+4 \mathrm{H}^{+}$. At G6, the sulphate produced by the same reaction is controlled by the precipitation of barite, which explain the very low $\mathrm{SO}_{4}{ }^{2-}$ contents. Whereas in the fresh water around the lagoa, and because of lower $\mathrm{Ba}^{2+}$ contents, the solution are undersaturated with respect to barite, the produced sulphate is not controlled and therefore reaches higher values. Similarly, the shape of the scatter plot of $\mathrm{F}^{-}$on Figure 8c could result, not from a sink of $\mathrm{F}^{-}$as supposed above, but from a source of $\mathrm{F}^{-}$that supply about $210^{-3} \mathrm{mM}$ of $\mathrm{F}^{-}$in the fresh water solution.

$\mathrm{K}^{+}$is likely to be involved in the formation of illite in the clay fraction of the grey and green layers close to the salina. $\mathrm{K}^{+}$is also adsorbed on the exchange complex as potassium equivalent fraction increases along the transect. Outside the alkaline environment, the dissolution of illite is a source of $\mathrm{K}^{+}$ in the fresh solution around the lagoa. It supplies about $10^{-1} \mathrm{mM}$ of $\mathrm{K}^{+}$in the solution for fresh waters with $\mathrm{Na}^{+}$between 0.07 and $0.2 \mathrm{mM}$. $\mathrm{Mg}^{2+}$ is also strongly affected by control processes. Part of the $\mathrm{Mg}$ 
is likely incorporated in the $\mathrm{Mg}$-calcite formation. However, $\mathrm{Mg}$ is also incorporated in the clay horizon, in the clay minerals or in the Si-cement.

\subsection{Influences on arsenic}

Three main geochemical processes are identified along the transect that influence the chemistry in the shallow groundwater and the lakes. They are: (1) concentration through evaporation [index word 3] and associated precipitations; (2) oxidation of sulphide minerals in the clay layer; (3) dissolution of the clay fraction. In this framework, the total dissolved arsenic seems to be regulated only by the evaporation process and arsenic results from conservative behaviour during evapo-concentration as shown in correlation to $\mathrm{Na}$ (slope very close to 1 ; fig. $8 \mathrm{~h}$ ).

Dissolved arsenic is usually controlled by adsorption processes that can take place on 3 main different adsorbents, namely metallic (Al, Fe and Mn) oxides and hydroxides, clay minerals and organic matter. However, in the geochemical environment of Nhecolândia, arsenic contents increase with the other dissolved species and their competitive adsorption [index word 16] (mainly with $\mathrm{HCO}_{3}^{-}, \mathrm{F}^{-}$) prevents arsenic from fixation onto any adsorbent. Moreover, arsenate adsorption on oxides and clays is highest at low $\mathrm{pH}$ and decreases with increasing $\mathrm{pH}$, namely, above $\mathrm{pH} 9$ for $\mathrm{Al}$ oxide, $\mathrm{pH} 7$ for Fe oxide or hydroxide, illite and kaolinite (Goldberg, 2002). The chemical conditions along the transect indicate that arsenic concentrations increase with increasing $\mathrm{pH}$ that reach values above 8-9, and therefore simultaneously decreases its adsorption affinities on mineral surfaces. Consequently, the solid phase does not appear to be a factor controlling dissolved arsenic, which therefore concentrates due to evaporation.

The calculated arsenic speciation [index word 1] from Eh-pH conditions is theoretical. Indeed, the kinetics of arsenic redox [index word 14] transformations between As(V) and As(III) redox states are relatively slow, and both oxidation states are often found in soils regardless of the redox conditions. However, the calculation offers a reasonable model for understanding the behaviour of arsenic along the sequence. $\mathrm{As}(\mathrm{V})$ dominates in the groundwater as well as in the saline lake. On the one hand, when the solution concentrates, $\mathrm{pH}$ increases favour the redox stability of $\mathrm{As}(\mathrm{V})$. On the other hand, DOC increases with increasing $\mathrm{pH}$ provoking low Eh values. Therefore, the As(III) redox state, which is known to be more acutely toxic than As(V), could occur in the most saline samples with high DOC and low Eh conditions between P3 and the salina. However, due to the high hydraulic conductivity of the sandy material in which the water table fluctuates, the flow between P3 and the salina is too fast to allow any change in the arsenic redox state. In the sediment of the salina, where low Eh is occurring constantly, and because of the long residence time of the solution, arsenic is likely to be As(III). As(III) may diffuse into the water through the turning over of the sediments by the cattle that comes to drink at the lake. Therefore, in this case the proportion of As(III) in the water could be under-estimated by the speciation modelling.

\section{Future directions}

The shallow groundwaters of this region of Nhecolândia are relatively depleted in calcium with respect to alkalinity and evolve into high alkalinity and high $\mathrm{pH}$ as solutions become more saline under the 
influence of evaporation. The water flows from the upland and from the freshwater lake toward the salina. Calcite precipitates on the shore of the saline lakes, and in the forested sand hills (cordilheira). Below the sand layer, in which the water table fluctuates, a continuous ring of clay material, often cemented by amorphous silica, is the result of evapo-concentration and illite precipitation. This ring acts as a barrier that prevents the back flow from the salina to the fresh-water aquifer. The sodium carbonate precipitation takes place during the dry season on the immediate shore of the saline lake. In this framework, the competition between arsenic and other species, as well as the high $\mathrm{pH}$ conditions do not favour As-solid phase reactions and dissolved arsenic evolve in proportion to sodium amount, i.e., proportionately to the evaporation process [index word 3]. Locally, the oxidation of sulphide mineral creates acidic conditions that are buffered by clay dissolution, but both processes have no influence on dissolved arsenic. As(V) was calculated to be the dominant form in the watertable, and in the lakes, but dissolved As(III) is likely to dominate in the sediment and could diffuse in the lake when the cattle turn over the sediment.

The results indicate that the arsenic currently present in the saline lakes does not arise from local Asrich minerals, but only from concentration of freshwaters with arsenic contents below the WHO [index word 12] maximum guidelines. Furthermore, estimate total arsenic concentrations in the lakes of Nhecolândia (EC- Arsenic, $r^{2}=0.97$ ). Therefore, further investigations should focus on 1- the regional representativity of this study carried out on the pilot area of the Nhumirím experimental farm and 2- the Arsenic speciation (As(III) / As(V)) in the soil solution of sediments in alkaline lakes.

\section{Acknowledgement}

This study has been realised in the framework of a CAPES-COFECUB cooperation (412/03) between France and Brazil. We thank EMBRAPA-Pantanal and SEMACT for logistical support, and Dr. Vasanthi Dass for editorial advice.

\section{References}

Almeida TIR, Sígolo JB, Fernandes E, Queiroz Neto JP, Barbiéro L, Sakamoto A (2003) Proposta de classificação e gênese das lagoas da baixa Nhecolândia-MS com base de sensoriamento remoto e dados de campo. Revista Brasileira de Geociências 33, 83-90.

Assine ML, Soares PC (2004) Quaternary of the Pantanal, west-central Brazil. Quaternary International 114, 23-34.

Barbiéro L, Valles V, Régeard A, Cheverry C (2001) Residual Alkalinity as a tracer to estimate the changes induced by a forage cultivation in a non saline sodic soil. Agricultural water Management 50, 229-241.

Barbiéro L, Queiroz Neto JP, Ciornei G, Sakamoto AY, Capellari B, Fernandes E, Valles V (2002) Geochemistry of water and ground water in the Nhecolândia, Pantanal of Mato Grosso, Brazil: variability and Associated processes. Wetlands 22, 528-540. 
Bhattacharya P, Frisbie SH, Smith E, Naidu R, Jacks G, Sarkar B (2002a) Arsenic in the environment: a global perspective. In 'Handbook of Heavy Metals in the Environment'. (Ed. B. Sarkar) pp. 147 -215. (Marcell Dekker Inc: New York)

Bhattacharya P, Jacks G, Ahmed KM, Khan AA, Routh J (2002b) Arsenic in groundwater of the Bengal Delta Plain aquifers in Bangladesh. Bulletin Environmental Contamination and Toxicology 69, $538-545$.

Bhattacharya P, Welch AH, Ahmed KM, Jacks G, Naidu R (2004) Arsenic in groundwater of sedimentary aquifers. Applied Geochemistry 19, 163-167.

Bundschuh J, Farias B, Martin R, Storniolo A, Bhattacharya P, Cortes J, Bonorino G, Albouy R (2004) Groundwater arsenic in the Chaco-Pampean Plain, Argentina: Case study from Robles county, Santiago del Estero Province. Applied Geochemistry 19, 231-243.

Chernet T, Travi Y, Valles V (2001) Mechanism of degradation of the quality of natural water in the lakes region of the Ethiopian rift valley. Water Ressources 35, 2819-2832.

Droubi A Al, Fritz B, Gac JY, Tardy Y (1980) Generalized residual alkalinity concept; Application to prediction of the chemical evolution of natural waters by evaporation. American Journal of Science 280, 560-572.

Eaton FM (1950) Signifiance of carbonates in irrigation waters. Soil Science 69, 123-133.

Furquím SC, Queiroz Neto JP, Furian S, Barbiéro L, Graham RC (2004) Mg-Mica Formation in Alkaline Environment of the Nhecolândia, South Mato Grosso, Brazil. Proceeding of the International Congress on Applied Mineralogy, Águas de Lindoias-S.P., Brazil.

Goldberg S (2002) Competitive adsorption of arsenate and arsenite on oxides and clay minerals. Soil Science Society of America Journal 66, 413-421.

Hamilton SK (1999) Potential effects of a major navigation project (Paraguay-Parana hidrovia) on inundation in the Pantanal floodplains. Regulated Rivers: Research \& Management 15, 289-299.

Hamilton SK, Corrêa de Souza O, Coutinho ME (1998) Dynamic of floodplain inundation in the alluvial fan of the Taquari River (Pantanal, Brazil). Verhandlungen der Internationalen Vereinigung für theoretische und angewandte Limnologie 26, 916-922.

Hardie LA, Eugster HP (1970) The evolution of close basin brines. Mineralogical Society of America Special Paper 3, 273-290.

Harvey CF, Swartz CH, Badruzzaman ABM, Keon-Blute N, Yu W, Ashraf Ali M, Jay J, Beckie R, Niedan V, Brabander D, Oates PM, Ashfaque KN, Islam S, Hemond HF, Feroze Ahmed M (2002) Arsenic mobility and groundwater extraction in Bangladesh. Science 298, 1602-1606.

Icole M, Masse JP, Perinet G, Taieb M (1990) Pleistocene lacustrine stromatolites, composed of calcium carbonate, fluorite, and dolomite, from Lake Natron, Tanzania: depositional and diagenetic processes and their paleoenvironmental significance. Sedimentary Geology 69, 139-155.

Klammer G (1982) Die Palaeowueste des Pantanal von Mato Grosso und die pleistozane Klimageschichte der brasilianischen Randtropen. Zeitschrift für Geomorphologie 26, 393-416. 
Maître V (1991) Protocole d'extraction, de conservation et de filtration des eaux libres du sol. Science du sol 29, 71-76.

Marlet S, Valles V, Barbiéro L (1996) Field study and simulation of geochemical mechanisms of soil alkalinisation in the sahelian zone of Niger. Arid soil research and rehabilitation 10, 243-256.

Morrison RIG, Manore M, Ross RK, Padovani CR (2000) Identificação das lagoas salinas da região da Nhecolândia - Pantanal, através de técnicas de sensoriamento remoto. III Simpósio sobre Recursos Naturais e Sócio-econômicos do Pantanal, Corumbá-MS (Resumo) 88-89.

Por FD (1995) 'The Pantanal of Mato Grosso (Brazil): World's Largest Wetlands'. (Kluwer Academic Publisher, Monographiae Biologicae 73: Dordrecht/Boston/London)

Scatchard G (1968) The excess free energy and related properties of solutions containing electrolytes. Journal of the American Chemical Society 90, $3124-3127$.

Smedley PL, Kinniburgh DG (2002) A review of the source, behaviour and distribution of arsenic in natural waters. Applied Geochemistry 17, $517-568$.

Smedley PL, Nicolli HB, McDonald DMJ, Barros AJ, Tullio JO (2002) Hydrogeochemistry of arsenic and other inorganic constituents in groundwaters from La Pampa, Argentina. Applied Geochemistry 17, 259-284.

Valles V, N'Diaye MK, Bernadac A, Tardy Y (1989) Geochemistry of water in the Kouroumari region, Mali. Al, Si and Mg in water concentrated by evaporation: development of a model. Arid Soil Research and Rehabilitation 3, 21-39.

Valles V, Ribolzi O, de Cockborne AM, Cornieles M (1996) Presentation de AQUA, logiciel de géochimie appliqué aux problèmes environnementaux. GRESSAP, 10 September 1996, ORSTOM, Montpellier.

Valles V, Rezagui M, Auque L, Semadi A, Roger L, Zouggari H (1997) Geochemistry of saline soils in two arid zones of the mediterranean basin. I. Geochemistry of the Chott Melghir-Mehrouane watershed in Algeria. Arid Soil Research and Rehabilitation 11, 71-84.

Van Beek CGE, van Breemen N (1973) The alkalinity of alkali soils. The Journal of Soil Science 24, 129-136.

Zhang R (1997) Determination of sorptivity and hydraulic conductivity from the disk infiltrometer. Soil Science Society of America Journal 61, 1024-1030.

Zheng Y, Stute M, van Geen A, Gavrieli I, Dhar R, Simpson HJ, Schlosser P, Ahmed KM (2004) Redox control of arsenic mobilization in Bangladesh groundwater. Applied Geochemistry 19, 201-214. 


\section{Index entries}

1 Arsenic speciation, .............................page number see insertion in the text

2 Toxicity,

3 Evaporation,

4 Principal Component Analysis,

5 Thermodynamic modelling,

6 Electrostatic interactions,

$7 \mathrm{O} 2$ fugacity,

$8 \mathrm{CO} 2$ partial pressure,

9 Alkalinity,

10 Residual alkalinity,

11 Generalised residual alkalinity,

12 WHO guideline,

13 acidity buffering,

14 Redox,

15 Variance,

16 Competitive adsorption. 


\section{FIGURE CAPTIONS}

Fig. 1. Location of the studied site (Nhecolândia, Pantanal, upper Paraguay basin).

Fig. 2. Location of the transect from freshwater lake to saline lake.

Fig. 3. Cross section showing the soil layout and the water table during dry and wet season.

Fig. 4. Fluctuation of the water level in P2 and P3 from October 1998 to October 2002. Grey sections are short periods of back propagation of the saline water to the freshwater aquifer.

Fig. 5. Distribution of water $\mathrm{pH}$ and EC along the transect in 2000, showing the saline and alkaline waters around the salina and the freshest water in the cordilheira. Note the low $\mathrm{pH}$ measured at G6.

Fig. 6. Distribution of the calculated arsenic speciation along the transect T1 in 2000.

Fig. 7. Distribution samples from 2000 and 2003 in Eh-pH stability diagram for aqueous As species in the system As- $\mathrm{O}_{2}-\mathrm{H}_{2} \mathrm{O}$ at $25^{\circ} \mathrm{C}$ and 1 bar total pressure. Closed circles are Eh-pH conditions in the sediments of the saline lake.

Fig. 8. Concentration diagrams (solid line $=$ unit slope line; dotted line $=$ simulation of evaporation, open circle are samples from G6, squared symbol is the most saline sample, where concentration factor based on sodium amount could be an underestimate) 


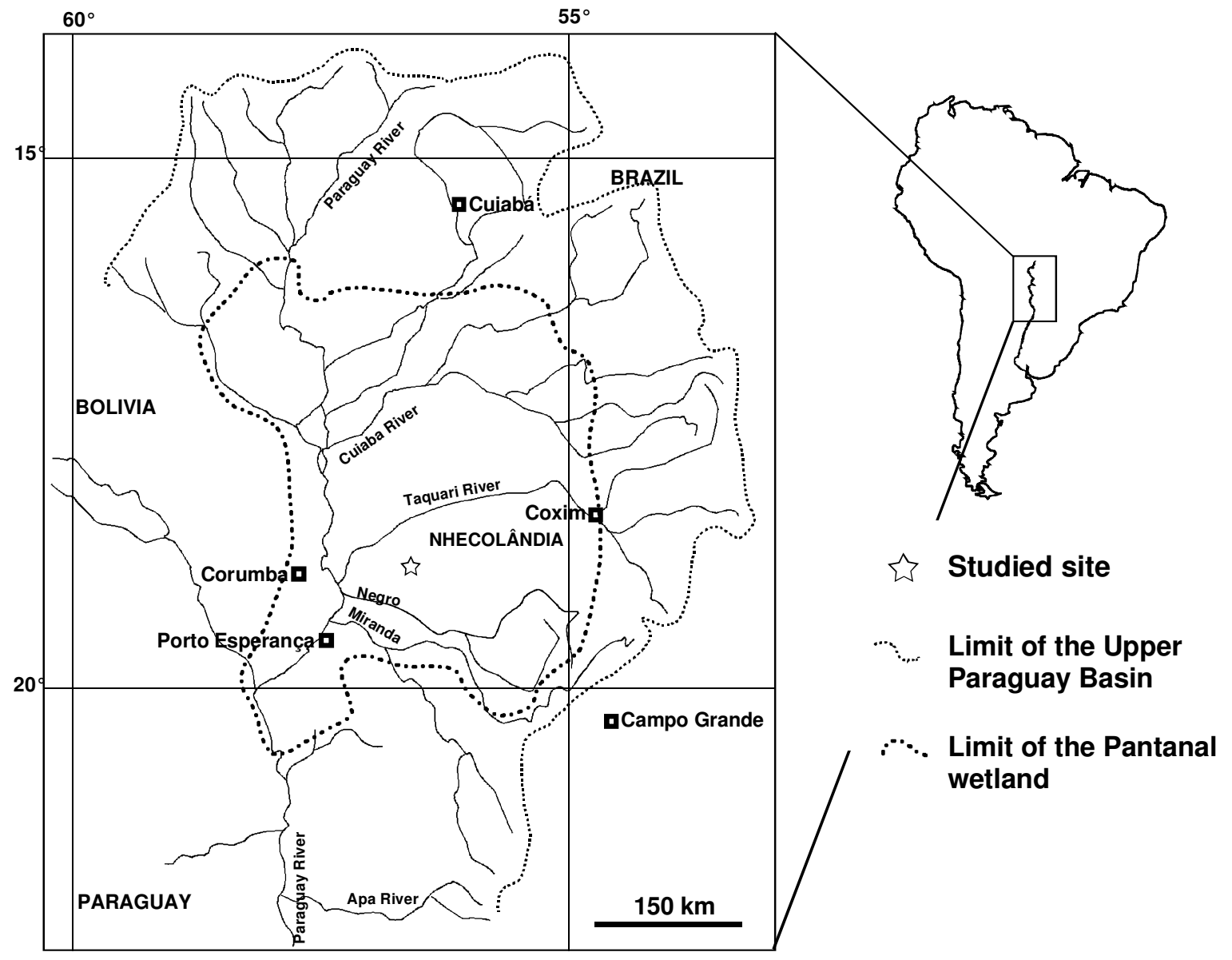

Fig. 1. Location of the studied site (Nhecolândia, Pantanal, upper Paraguay basin). 


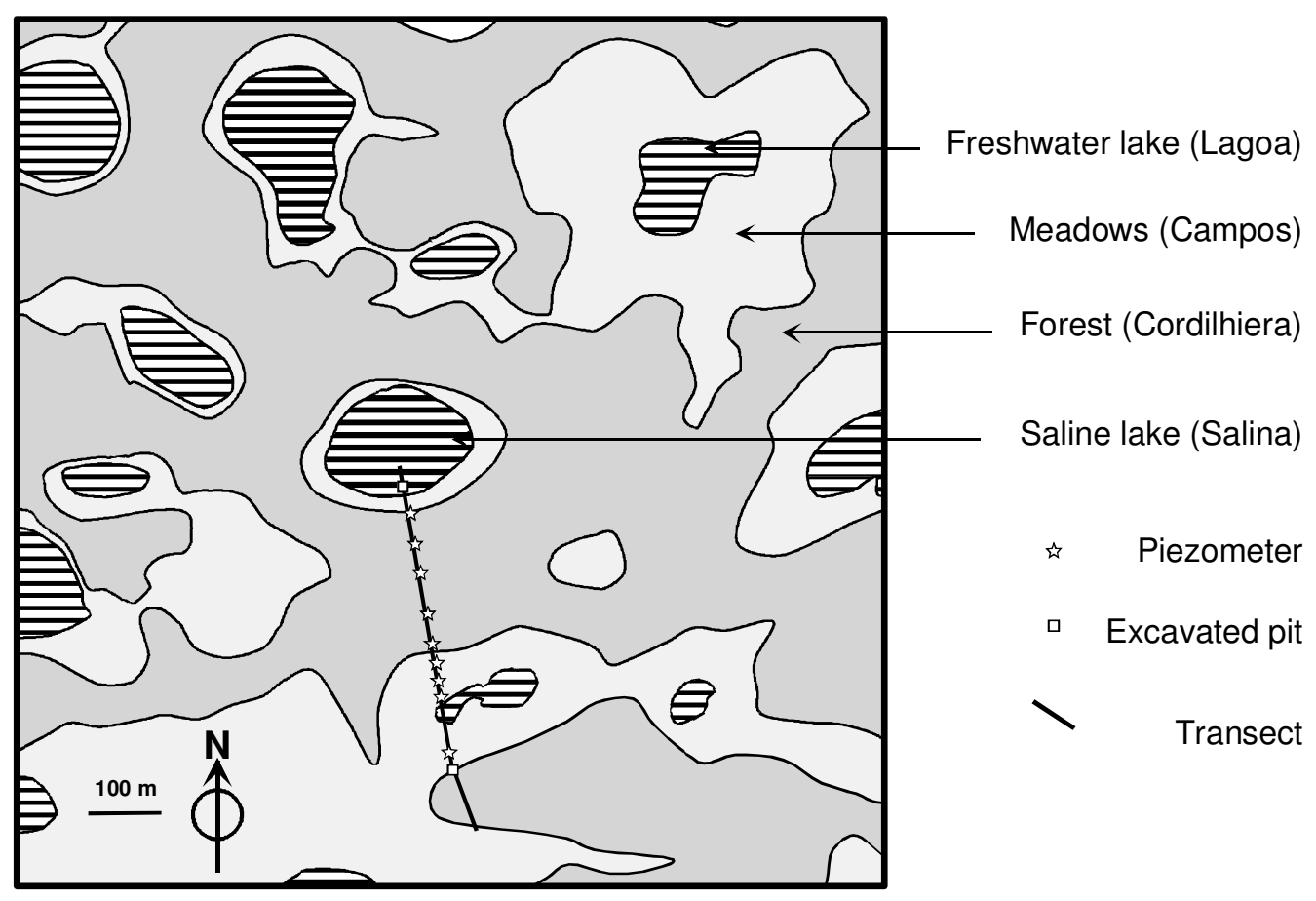

Fig. 2. Location of the transect from freshwater lake to saline lake. 


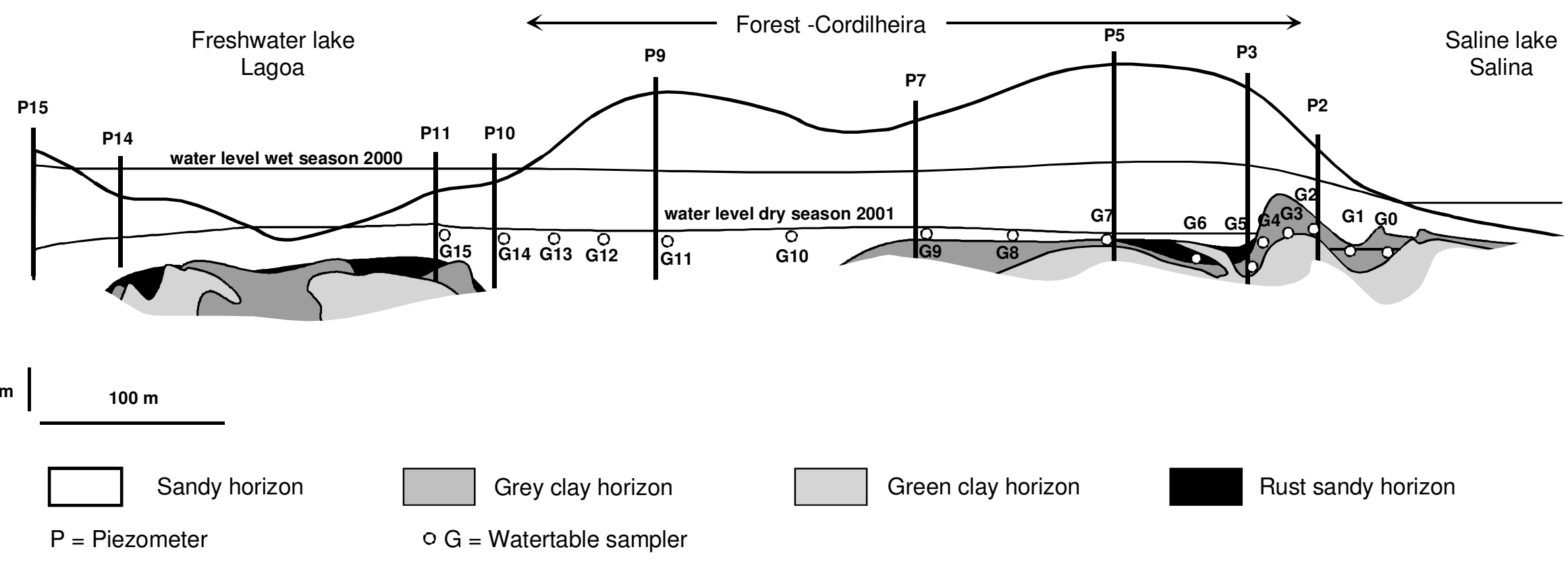

Fig. 3. Cross section showing the soil layout and the water table during dry and wet season. 


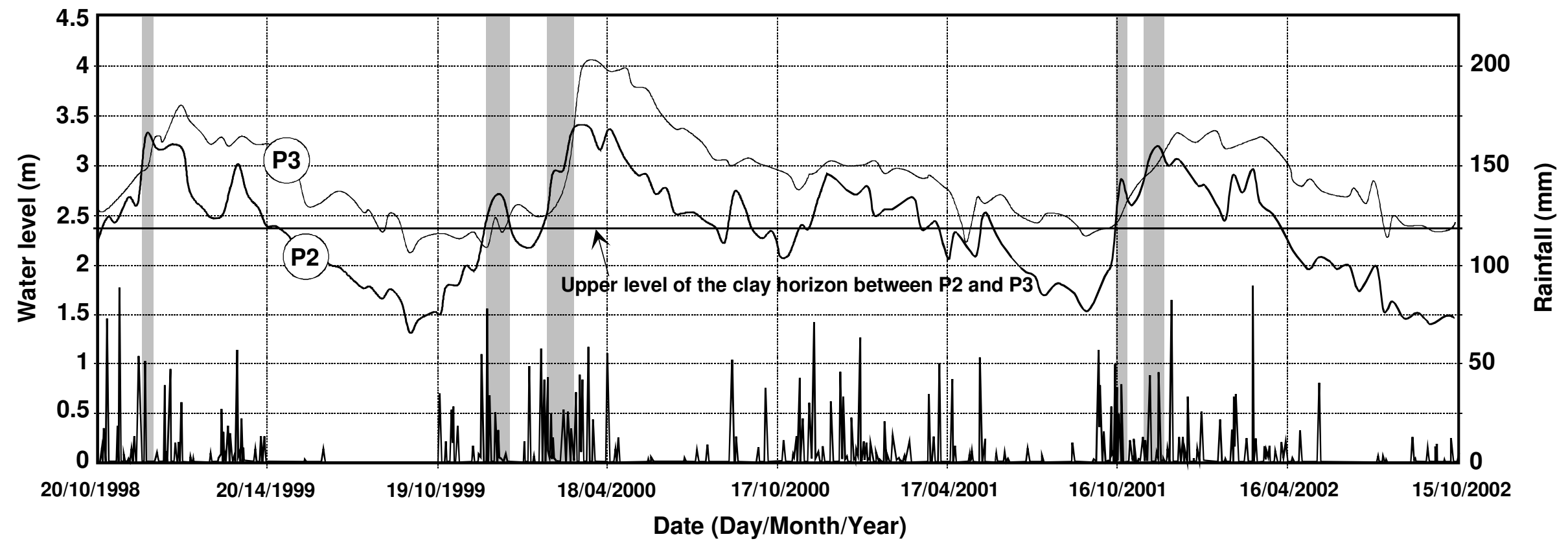

Fig. 4. Fluctuation of the water level in P2 and P3 from October 1998 to October 2002. Grey sections are short periods of back propagation of the saline water to the freshwater aquifer. 

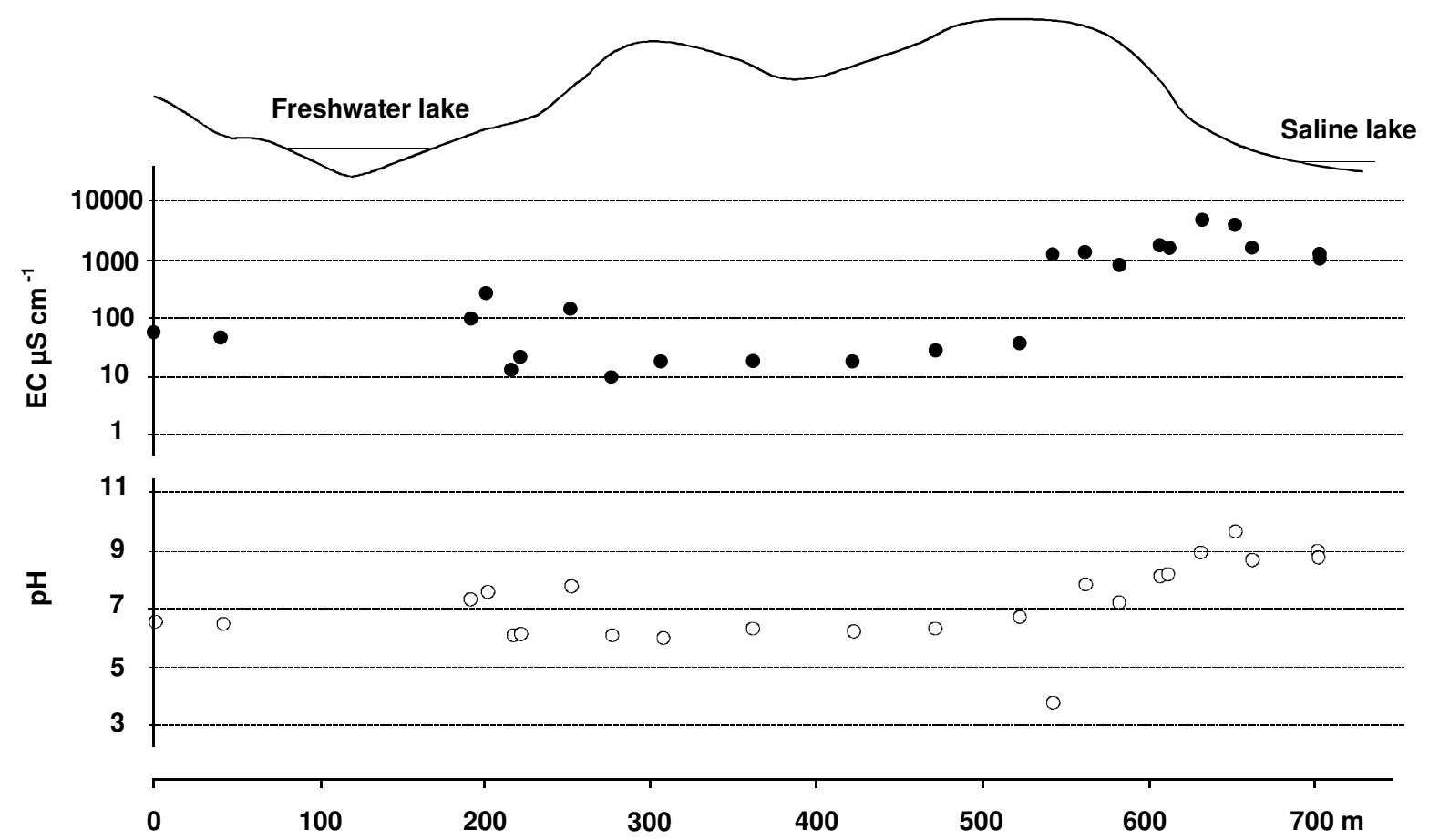

Fig. 5. Distribution of water $\mathrm{pH}$ and EC along the transect in 2000, showing the saline and alkaline waters around the salina and the freshest water in the cordilheira. Note the low pH measured at G6. 

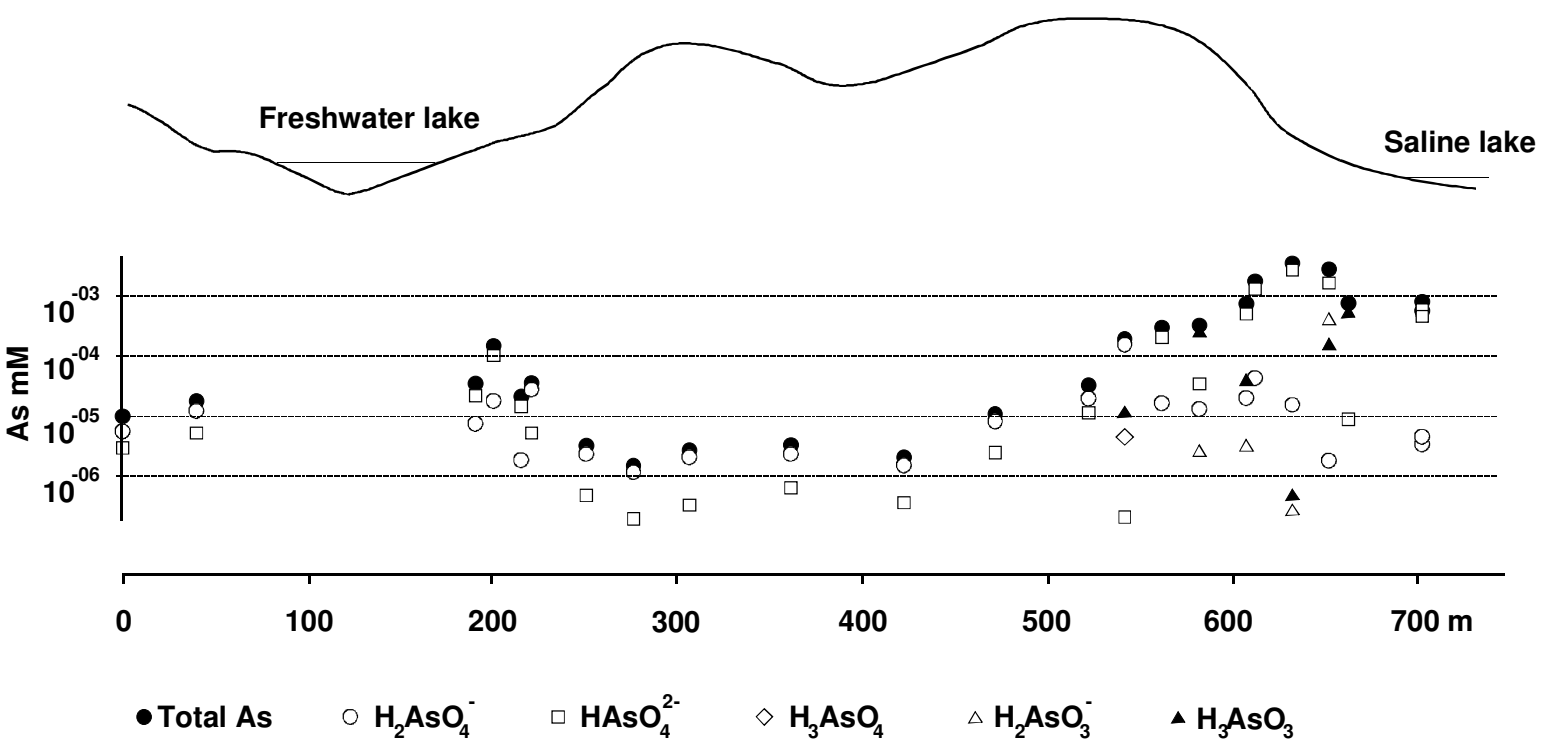

Fig. 6. Distribution of the calculated arsenic speciation along the transect T1 in 2000. 


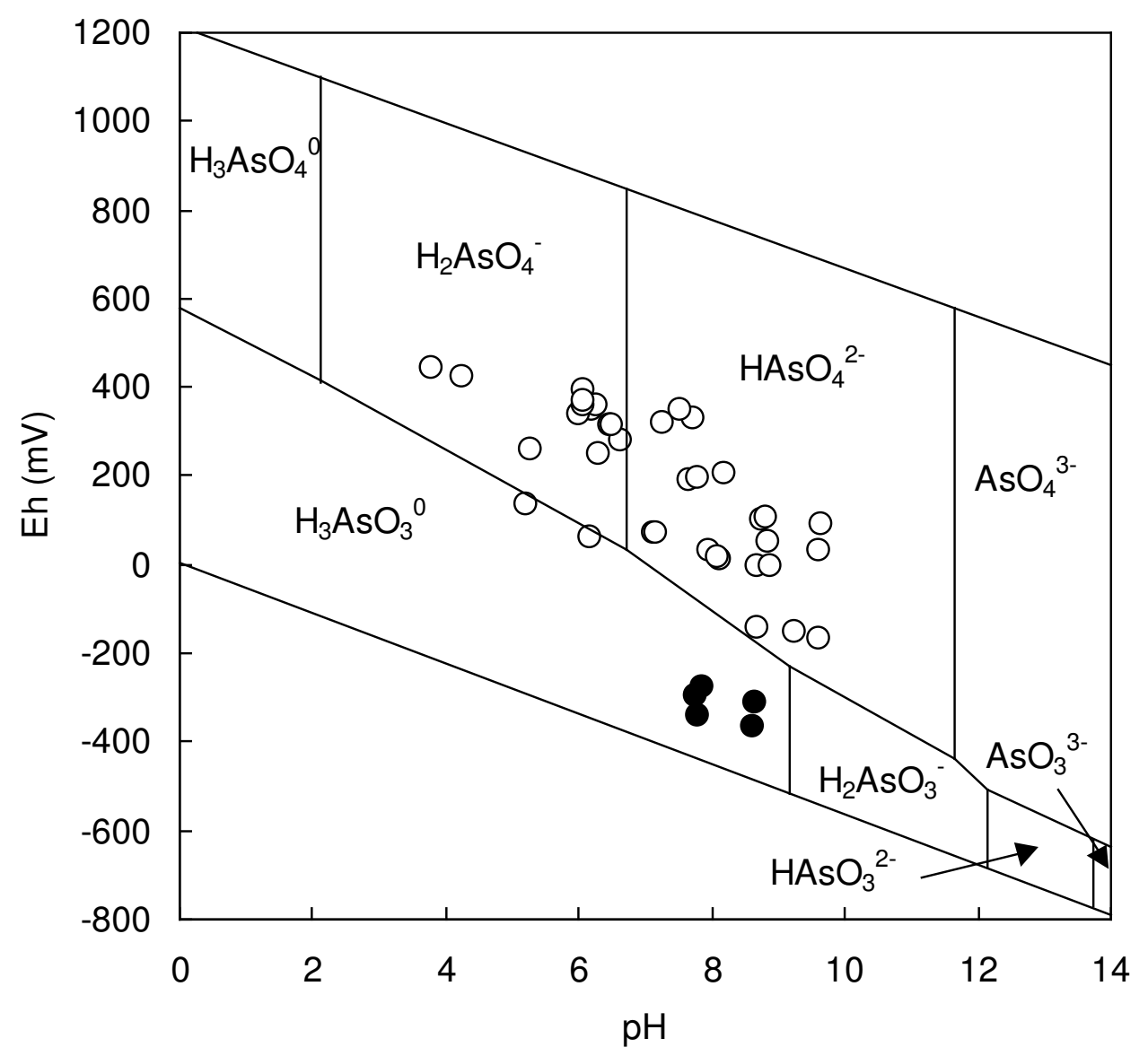

Fig. 7. Distribution samples from 2000 and 2003 in Eh-pH stability diagram for aqueous As species in the system As- $\mathrm{O}_{2}-\mathrm{H}_{2} \mathrm{O}$ at $25^{\circ} \mathrm{C}$ and 1 bar total pressure. Closed circles are Eh-pH conditions in the sediments of the saline lake. 

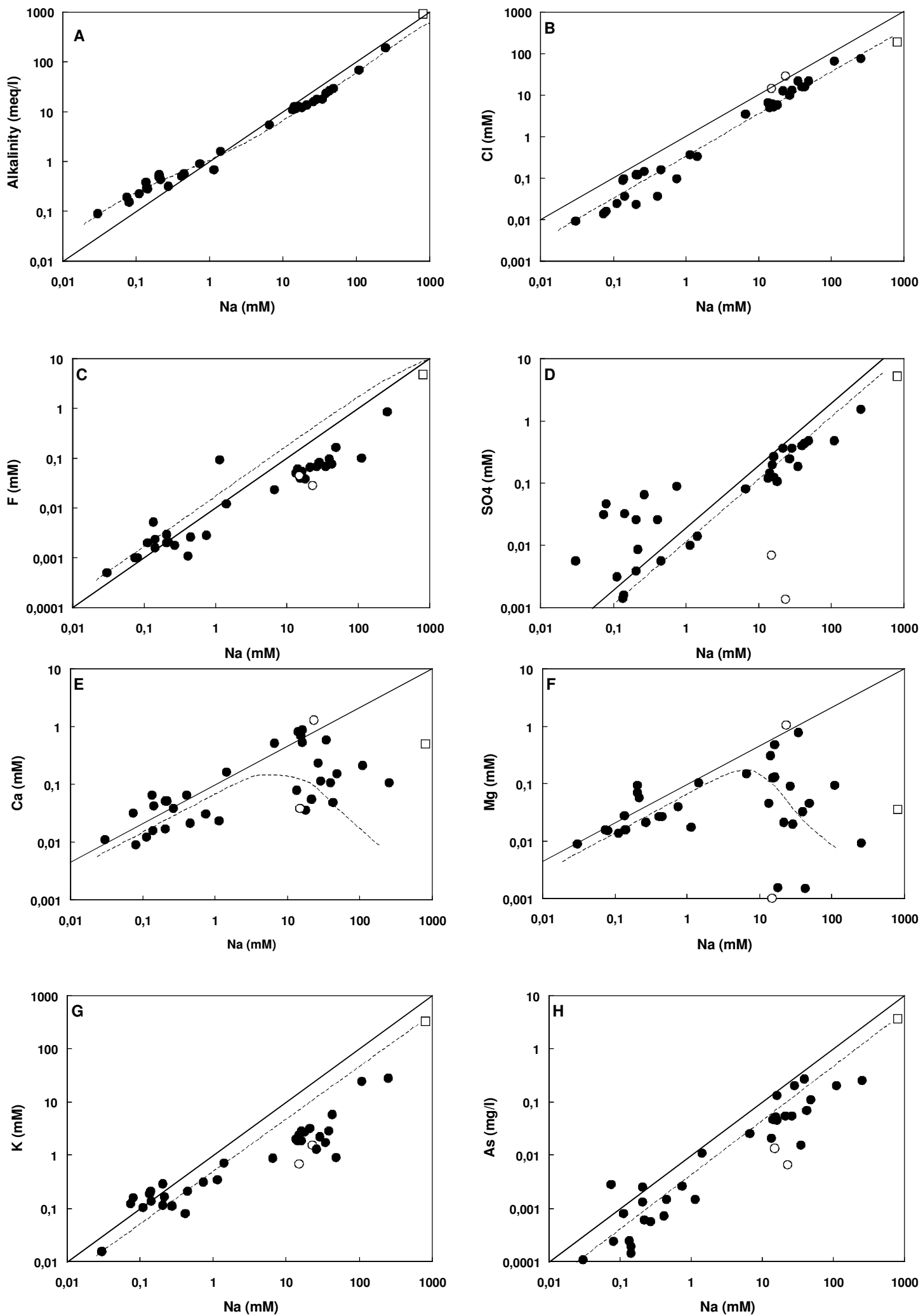

Fig. 8. Concentration diagrams (solid line $=$ unit slope line; dotted line $=$ simulation of evaporation, open circle are samples from G6, squared symbol is the most saline sample, where concentration factor based on sodium amount could be an underestimate) 


\section{TABLE CAPTIONS}

Table 1 Summary statistical data for field measurements, major constituents and arsenic.

Table 2 Singular values of the Principal Component Analysis (PCA). 
Table 1

Summary statistical data for field measurements, major constituents and arsenic

\begin{tabular}{lcccccc}
\hline Variable & Units & Minimum & Maximum & Average value & Variance $(v)^{*}$ & $\begin{array}{c}\text { Relative Standard } \\
\text { Deviation }\end{array}$ \\
\hline $\mathrm{pH}$ & & 3.77 & 9.64 & 7.29 & 2.26 & 0.21 \\
Eh & $\mathrm{mV}$ & -170 & 439 & 173 & 29431 & 0.99 \\
Temperature & ${ }^{\circ} \mathrm{C}$ & 28.4 & 41.6 & 31.6 & 13.8 & 0.12 \\
$\mathrm{E} . \mathrm{C}$. & $\mu \mathrm{S} / \mathrm{cm}$ & 9.6 & 73300 & 4256 & $15.5910^{7}$ & 2.93 \\
$\mathrm{Ca}$ & $\mathrm{mmol} / 1$ & $910^{-3}$ & 1.312 & 0.215 & $9.6410^{-2}$ & 1.44 \\
$\mathrm{Mg}$ & $\mathrm{mmol} / 1$ & $110^{-3}$ & 1.044 & 0.111 & $4.8810^{-2}$ & 1.99 \\
$\mathrm{Na}$ & $\mathrm{mmol} / 1$ & $310^{-2}$ & 814 & 43.79 & 19483 & 3.19 \\
$\mathrm{~K}$ & $\mathrm{mmol} / 1$ & $1.510^{-3}$ & 326 & 11.64 & 2949 & 4.66 \\
$\mathrm{Cl}$ & $\mathrm{mmol} / 1$ & $910^{-3}$ & 192 & 14.77 & 1218 & 2.36 \\
$\mathrm{SO} 4$ & $\mathrm{mmol} / 1$ & $110^{-3}$ & 5.23 & 0.312 & 0.786 & 2.94 \\
$\mathrm{Alkalinity}$ & $\mathrm{meq} / \mathrm{l}$ & -0.48 & 940 & 40.1 & 24959 & 3.94 \\
$\mathrm{Si}$ & $\mathrm{mmol} / 1$ & 0.11 & 3.74 & 0.887 & 0.982 & 1.64 \\
$\mathrm{~F}$ & $\mathrm{mmol} / 1$ & $10^{-3}$ & 4.737 & 0.191 & 0.628 & 4.14 \\
As & $\mathrm{mmol} / 1$ & $1.110^{-4}$ & 3.68 & 0.148 & 0.372 & 4.12 \\
$\mathrm{DOC}$ & $\mathrm{mg} / \mathrm{l}$ & 0.44 & 1102 & 96.74 & 53282 & 2.39 \\
\hline
\end{tabular}

(*) $\quad v=\frac{1}{n} \sum_{i=1}^{n}\left(x_{i}-\bar{x}\right)^{2} \quad$ with $\quad \bar{x}=\frac{1}{n} \sum_{i=1}^{n} x_{i}$ 
Table 2

Singular values of the Principal Component Analysis (PCA)

\begin{tabular}{lcc}
\hline Axis & \% of the variance $(v)^{*}$ & \% of the variance cumulated \\
\hline 1 & 66.11 & 66.11 \\
2 & 14.02 & 80.13 \\
3 & 11.44 & 91.57 \\
4 & 3.34 & 94.91 \\
\hline
\end{tabular}

* See Table 1 